\title{
Evaluation of competitive ability of two heterotrophic planktonic bacteria under phosphorus limitation
}

\author{
Olav Vadstein* \\ Trondhjem Biological Station, Norwegian University of Science and Technology, N-7034 Trondheim, Norway
}

\begin{abstract}
Competitive ability for phosphorus of 2 heterotrophic bacteria, isolated from the photic zone of a lake, was investigated by a growth kinetic characterization in batch cultures using a radioactive tracer. Key characteristics chosen were based on a competition model verified under both steady state and non steady state conditions in previous studies. The characterization included determination of $\mathrm{P}$ requirement, uptake kinetic parameters anct release rates of dissolved inorganic phosphate $\left(P_{1}\right)$. The 2 bacteria exhibited different kinetic properties that may reflect differences in competitive strategies. Strain 3 h seemed to be adapted to competition at more transient or pulsed supply modes of $P_{1}$, as reflected by its $\mathrm{P}$-specific maximum uptake rate, which was 4 times higher than that of strain $2 \mathrm{~g}$. Strain $2 \mathrm{~g}$, on the other hand, seemed to be a better competitor at uniform or moderately pulsed $P_{1}$ supply modes. This is due to a better ability to maintain positive net $P_{1}$ uptake at low concentrations, with the critical concentration for positive net uptake being a factor of 2 lower for strain $2 \mathrm{~g}$ than for strain $3 \mathrm{~h}$. A comparison with typical values of kinetic parameters published for cyanobacteria and green algae suggest that cyanobacteria may be better competitors than the heterotrophic bacteria at transient supply modes of $P_{\mathrm{i}}$, whereas green algae have a comparable or better ability than the heterotrophic bacteria to compete for $\mathrm{P}$ at uniform supply modes of $P_{\mathrm{i}}$. These conclusions are based on relatively few data, with considerable within-group variation, and should therefore be considered with caution.
\end{abstract}

KEY WORDS: Bacteria $\cdot$ Phosphorus · Nutrients · Uptake $\cdot$ Competition · Elemental ratios

\section{INTRODUCTION}

Bacteria are normally considered superior competitors for inorganic phosphate and are therefore believed to be limited by carbon/energy (Currie \& Kalff $1984 \mathrm{a}$, b). However, phosphorus (P) sub-saturation of heterotrophic bacteria in freshwater and marine systems has been reported and the addition of inorganic $P$ often stimulates the growth of bacteria (cf. Vadstein et al. 1988, Morris \& Lewis 1992, Vadstein 1998, Thingstad et al. 1997). These findings may be contradictory to the conclusion that bacteria are superior competitors for P. In addition to selective loss rates of bacteria (cf. Thingstad et al. 1997), this possible discrepancy may be explained by an insufficient evaluation of competitive ability or methodological problems with assessment of $\mathrm{P}$ status of natural bacterial communities.

\footnotetext{
•E-mail: olav.vadstein@vm.ntnu.no
}

It has been shown that the release or exchange of $\mathrm{P}$ from planktonic organisms to the surrounding environment is a process that, albeit frequently overlooked, can dramatically alter the outcome of a competition situation (Olsen et al. 1989). Moreover, evaluations of competitive ability based solely on uptake kinetics of inorganic phosphorus may lead to erroneous conclusions regarding competitive ability.

To my knowledge, the release of $P$ from healthy heterotrophic bacteria has not been quantified with appropriate methods in an ecologically relevant context, although it is well established that bacteria do release P (Rosenberg et al. 1982, Jansson 1988). Because such a release to a large extent is counterbalanced by re-uptake in a culture, the estimation of $P$ release rates are difficult and may easily be underestimated. In the literature 2 different methods that take into account this problem have been applied to estimate release rates from planktonic algae: (1) mass bal- 
ance measurement under steady state conditions (Olsen 1989) and (2) kinetic studies using radioactive phosphorus (Lean \& Nalewajko 1976).

The aim of the reported study was to characterize the competitive ability for $\mathrm{P}$ of 2 heterotrophic bacteria isolated from a limnetic water column, by studying their kinetic properties. Chosen key characteristics were based on a competition model that has been verified under both steady state and non steady state conditions using a cyanobacterium and a eucaryotic alga (Olsen 1988, Olsen et al. 1989). The model requires knowledge on $\mathrm{P}$ requirement, uptake kinetic parameters and release rates of $\mathrm{P}$.

\section{RELEVANT PROCESSES AND PARAMETERISATION OF THE COMPETITION MODEL}

The evaluation of competitive ability is based on a physiological model that includes concentrationdependent uptake of phosphate, ability to retain ac-

Table 1. List of symbols used in the text

\footnotetext{
Concentrations

$P_{\mathrm{i}} \quad$ Dissolved inorganic phosphate, $\mu \mathrm{g} \mathrm{\textrm {Pl } ^ { - 1 }}$

$P^{*} \quad$ Steady state concentration of $P_{1}$ at which the net uptake equals $\mu Q_{p}, \mu g \mathrm{Pl}^{-1}$

$P_{\mathrm{C}} \quad$ Steady state concentration of $P_{\mathrm{i}}$ at which the net uptake is zero and the uptake equals the release, $\mu \mathrm{g} \mathrm{Pl^{-1 }}$

$Q_{\mathrm{P}} \quad$ Phosphorus per unit bacterial biomass, $\mu \mathrm{g} \mathrm{P}(\mathrm{mg}$ C) $)^{-1}$

$Q_{0} \quad$ Subsistence quota, i.e. the value of $Q_{\mathrm{p}}$ at which $\mu=$ $0, \mu \mathrm{g} P(\mathrm{mg} \mathrm{C})^{-1}$

$Q_{\mathrm{m}} \quad$ Lowest value of $Q_{\mathrm{p}}$ at which maximum growth rate occurs, $\mu \mathrm{g} \mathrm{P}(\mathrm{mg} \mathrm{C})^{-1}$

$Q_{\mathrm{S}} \quad$ Value of $Q_{p}$ at $\mathrm{P}$ saturation, $\mu \mathrm{g} \mathrm{P}\left(\mathrm{mg} \mathrm{C}^{-1}\right.$

$k_{\mathrm{m}} \quad$ Half saturation constant for uptake, $\mu \mathrm{g} \mathrm{P} \mathrm{l}^{-1}$

$k_{\mathrm{S}} \quad$ Half saturation constant for growth, $\mu \mathrm{g} \mathrm{P} \mathrm{^{-1 }}$

Rates

$\mu \quad$ Specific growth rate, $h^{-1}$

$\mu_{m} \quad$ Maximum specific growth rate, $h^{-1}$

$\mu_{m}^{\prime} \quad$ Apparent maximum specific growth rate, i.e. the value of $\mu$ when yield is extrapolated to zero, or at infinite $Q_{\mathrm{p}}$ as given by the Droop model, $\mathrm{h}^{-1}$

$v \quad$ Specific cell carbon based uptake rate, $\mu \mathrm{g}$ P (mg C $h)^{-1}$

$u \quad$ Specific cell phosphorus based uptake rate, $\mathrm{h}^{-1}$

$V_{\mathrm{m}} \quad$ Maximum specific cell carbon based uptake rate, $\mu g \mathrm{P}(\mathrm{mg} \mathrm{Ch})^{-1}$

$U_{\mathrm{m}} \quad$ Maximum specific cell phosphorus based uptake rate, $\mathrm{h}^{-1}$

$A_{C} \quad$ Cellular $C$ based affinity of the $P_{1}$ uptake (i.e. $V_{m}$ $\left.k_{\mathrm{m}}^{-1}\right), 1\left(\mathrm{mg} \mathrm{C} \mathrm{h}^{-1}\right.$

$A_{\mathrm{F}} \quad$ Cellular $\mathrm{P}$ based affinity of the $P_{1}$ uptake (i.e. $U_{\mathrm{m}}$ $\left.k_{\mathrm{m}}^{-1}\right), 1(\mathrm{mg} \mathrm{P} \mathrm{h})^{-1}$

$S R_{\mathrm{P}}$ Specific cellular $\mathrm{P}$ based release rate of $P_{1}, \mathrm{~h}^{-1}$
}

quired $\mathrm{P}$, and utilisation of $\mathrm{P}$ for growth. The ability to store $\mathrm{P}$ is also considered. These factors are sufficient to predict the outcome of competition for phosphorus between a cyanobacterium and a eucaryotic alga under various phosphate supply modes (Olsen 1988, Olsen et al. 1989). Those studies indicate that the release of $P$ from organisms may affect the outcome of species competition for $P$.

The gross uptake of dissolved inorganic phosphate $\left(P_{\mathrm{i}}\right)$ by microorganisms is usually described by a saturation hyperbola of the Michaelis-Menten type (Cembella et al. 1984, Vadstein \& Olsen 1989), where the specific uptake rate $(u)$ is a function of the $P_{i}$ concentration and can be expressed by the maximum specific uptake rate $\left(U_{\mathrm{m}}\right)$ and the half saturation constant $\left(k_{\mathrm{m}}\right)$ :

$$
u=U_{\mathrm{m}} \frac{P_{\mathrm{i}}}{k_{\mathrm{m}}+P_{\mathrm{i}}}
$$

(symbols defined in Table 1). At high concentrations of $P_{\mathrm{i}}$ the uptake rate of the organism is well described by $U_{\mathrm{m}}$, whereas at low $P_{1}$ concentrations it is described by the affinity $\left(A_{P}\right)$. Here I have defined affinity as the first derivative of Eq. (1) at zero $P_{1}$ concentration; i.e. $U_{\mathrm{m}} / k_{\mathrm{m}}$ (Healey 1980). Instead of P-specific uptake, normalization can also be made to carbon biomass by multiplication of $u, U_{m}$ and $A_{p}$ with $Q_{p}$, to obtain $v, V_{m}$ and $A_{C \text { r }}$ respectively.

The phosphorus-specific release rates of $P_{1}\left(S R_{\mathrm{p}}\right)$ can be calculated as the difference between the gross specific uptake of $P_{\mathrm{i}}(u)$ and the net specific uptake rate at a given concentration of $P_{\mathrm{i}}$, which is the sum of the specific growth rate ( $\mu$ ) and the specific change in the cellular phosphorus content $\left(Q_{\mathrm{P}}\right)$ :

$$
S R_{\mathrm{p}}=u-\left(\frac{\mathrm{d} Q_{\mathrm{P}}}{\mathrm{d} t} \frac{1}{Q_{\mathrm{p}}}+\mu\right)
$$

At steady state growth, no changes in the cellular phosphorus content occur, and Eq. (2) reduces to:

$$
S R_{\mathrm{P}}=u-\mu
$$

Both $u$ and $\mu$ can be averaged on a daily basis or any other appropriate time interval. Previous studies, although limited, have shown that inorganic phosphate is the main form of released $P$ from a variety of microorganisms (Lean \& Nalewajko 1976, Robertson \& Button 1979) and from higher plants (Bieleski \& Ferguson 1983).

Droop (1968) demonstrated that there was a hyperbolic relationship between the cellular concentration or cell quota $\left(Q_{\mathrm{p}}\right)$ of the limiting nutrient, in this case $\mathrm{P}$, and the specific growth rate $(\mu)$ :

$$
\mu=\mu_{\mathrm{m}}^{\prime}\left(1-\frac{Q_{0}}{Q_{\mathrm{p}}}\right)
$$

The parameter $\mu_{m}^{\prime}$ is the asymptotic value of $\mu$ for infi- 
nite $Q_{p}$, and the parameter $Q_{0}$ is the minimum cell quota necessary for growth and is termed the subsistence quota. The growth rate is equal to the maximum growth rate $\left(\mu_{\mathrm{m}}\right)$ when $Q \geq Q_{\mathrm{m}}$. The Droop model can be applied to describe P-limited growth of heterotrophic bacteria (Vadstein 1998); the variations in cellular $P$ content with growth conditions make the Monod model inappropriate under non steady state conditions.

Cells have a maximum attainable cellular phosphorus content $\left(Q_{\mathrm{S}}\right)$ that can be reached under phosphorus sufficient conditions. The ratio between $Q_{\mathbb{S}}$ and $Q_{0}$, which may be termed the specific storage capacity of phosphorus, reflects the maximum biomass increase possible without further supply of phosphorus. $Q_{\mathrm{S}}$ must not be confused with $Q_{\mathrm{m}}$, which is the lowest $Q_{\mathrm{p}}$ supporting a growth rate equal to $\mu_{m}$.

From the above equations the relationships between ambient concentration of $P_{\mathrm{i}}$ and kinetic parameters can be calculated. Eq. (3) can be rearranged to express the steady state gross specific $P_{\mathrm{i}}$ uptake as a sum:

$$
u=S R_{\mathrm{P}}+\mu
$$

By substituting $u$ with Eq. (1) in Eq. (5), and solving for the steady state $P_{\mathrm{i}}$ concentration that gives an uptake sufficient to supply steady state growth $\left(P^{\bullet}\right)$, the following relationship is obtained:

$$
P \cdot=\frac{k_{m}\left(S R_{\mathrm{P}}+\mu\right)}{U_{m}-\left(S R_{\mathrm{P}}+\mu\right)}
$$

When $U_{\mathrm{m}} \gg\left(\mu+S R_{\mathrm{p}}\right)$, Eq. (6) reduces to:

$$
p \cdot \approx \frac{S R_{\mathrm{P}}+\mu}{A_{\mathrm{P}}}
$$

$P^{*}$ is the variable normally used to predict competitive ability of a species (Tilman 1977, Tilman et al. 1982) and is usually described by the Monod model. As previously noted, the Monod model applies only to steady state conditions and deviations from the model have been observed at low growth rates (Droop 1983, Olsen 1989).

Under non steady state conditions, another variable is more appropriate for predicting competitive ability of a species at low $P_{1}$ concentrations (Olsen 1988, Olsen et al. 1989). This variable is defined as the $P_{\mathrm{i}}$ concentration at which the uptake rate of $P_{\mathrm{i}}$ equals the release rate; i.e. when the net uptake rate equals zero $\left(P_{\mathrm{C}}\right)$ :

$$
P_{\mathrm{C}}=\frac{k_{\mathrm{m}} S R_{\mathrm{P}}}{U_{\mathrm{m}}-S R_{\mathrm{p}}}
$$

If $U_{\mathrm{m}} \gg S R_{\mathrm{P}}$ Eq. (8) reduces to:

$$
P_{\mathrm{C}} \approx \frac{S R_{\mathrm{p}}}{A_{\mathrm{P}}}
$$

For both $P^{*}$ and $P_{C}$, low values indicate good competitive ability for $P$ at low concentrations.
Because the uptake curve approximates a straight line with slope $A_{\mathrm{p}}$ at low $P_{\mathrm{i}}$ concentrations, predictions of competitive ability between species by use of both $P^{\cdot}$ and $P_{C}$ will be equal only if the affinities of the species are equal. If the affinities are different, predictions of competitive ability may be different, depending on

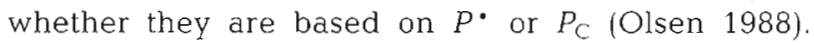
Competition experiments and model simulations have shown that use of $P_{C}$ leads to better predictions of competitive ability for $P_{\mathrm{j}}$ than use of $P^{*}$ (Olsen et al. 1989).

In summary, the ability of a species to compete for phosphate under uniform or moderately pulsed supply modes can be predicted from the $P_{C}$ value. This variable is proportional to the release rate of phosphate $\left(S R_{\mathrm{P}}\right)$ and inversely proportional to the affinity for phosphate $\left(A_{\mathrm{P}}\right)$. Under variable or pulsed supply modes of phosphate, the maximum uptake rate $\left(U_{\mathrm{m}}\right)$ and the storage capacity $\left(Q_{S}: Q_{0}\right)$ are important in addition to the $P_{C}$. For extremely pulsed supply, the maximum specific growth rate $\left(\mu_{m}\right)$ is also of significance.

\section{MATERIALS AND METHODS}

Organisms and culture conditions. The 2 bacterial strains used were isolated from epilimnetic water during summer in the eutrophic Lake Nesjøvatn, Central Norway. Water was spread on agar plates made from the WC mineral medium of Guillard \& Lorenzen (1972) with $1.0 \mathrm{~g}$ glucose and $15 \mathrm{~g}$ agar (Difco) added per litre. Pure cultures were kept in liquid medium made according to the same recipe, but with Tris- $\mathrm{HCl}$ buffer of $\mathrm{pH} 7.0$ added for $\mathrm{pH}$ control. Both strains were Gram negative rods. Whereas strain $3 \mathrm{~h}$ was not motile and did not produce acid from glucose, strain $2 \mathrm{~g}$ had both these characteristics.

Inoculum for the cultures was made by incubation of a culture overnight to obtain exponentially growing cells. The cultures ( 0.5 l culture volume) received a $5.0 \mathrm{ml}$ inoculum at the start of the experiment, and at time zero $P$ in bacterial cells was $<0.5 \%$ of total $P$ in the culture. The temperature was kept at $20.0 \pm 0.5^{\circ} \mathrm{C}$. Mixing and oxygen supply were provided by bubbling with sterile, moist air. Total P was 154 and $309 \mu_{\mathrm{g} \mathrm{P}} \mathrm{l}^{-1}$ for strain $2 \mathrm{~g}$ and 3 h, respectively. Growth of the cultures was followed by optical density measurements $(420 \mathrm{~nm})$ in a Shimadzu double beam UV-150-02 spectrophotometer. The readings were converted to particulate carbon by empirical relationships established for each bacterial strain. Strain $2 g: \operatorname{mg~C~} \mathrm{l}^{-1}=237\left[1-\sqrt{ }\left(1-0.849 A_{420}\right)\right]$ and strain 3h: $\mathrm{mg} \mathrm{C} \mathrm{l}^{-1}=300\left[1-\sqrt{ }\left(1-0.501 A_{420}\right)\right]$.

For both species 2 cultures were inoculated simultaneously. The 2 cultures were identical in all respects except that ${ }^{33} \mathrm{P}_{-} \mathrm{PO}_{4}$ was added to one of them to a final radioactivity of $10000-30000 \mathrm{CPM} \mathrm{ml}^{-1}$. 
Measurement of phosphorus compartments. The distribution of ${ }^{33} \mathrm{P}$ in the cultures with time was used to determine the distribution of dissolved and particulate $P$ through the growth phase. At intervals indicated in Figs. 1 \& 2, 2 samples of $0.5 \mathrm{ml}$ each were used to determine total ${ }^{33} \mathrm{P}$. Two $2.5 \mathrm{ml}$ samples were filtered on membrane filters (Millipore GS, pore size $0.22 \mathrm{~mm}$ ) under weak suction $(<0.2$ bar), and the filtrate was used to determine total dissolved and dissolved organic $P$.

The concentration of total dissolved $\mathrm{P}$ was determined by measuring ${ }^{33} \mathrm{P}$ in $0.5 \mathrm{ml}$ of the filtrate. The concentration of dissolved organic $\mathrm{P}$ was determined in samples after extraction of the phosphate-molybdate complex into an organic solvent (Koroleff 1976). An appropriate amount of $P$ molybdate reagents was added to a $2 \mathrm{ml}$ sample, which was then allowed to stand for $30 \mathrm{~min}$ in a closed centrifuge tube. Isobutylacetate was added in a water:solvent ratio of $1: 2$, and the sample was vigorously shaken for $1 \mathrm{~min}$. After the extraction, the sample was centrifuged to separate the organic and the aqueous phases, and the solvent was removed and discharged. Samples of $0.5 \mathrm{ml}$ were taken from the aqueous phase and used for counting of ${ }^{33} \mathrm{P}$. Tests demonstrated $>99 \%$ extraction efficiency under these conditions. The concentration of dissolved inorganic $P$ was estimated as the difference between total dissolved $\mathrm{P}$ and dissolved organic $\mathrm{P}$.

Fractionation of cellular $P$ into some main cellular compartments was done at early stationary phase. Samples of $2.5 \mathrm{ml}$ were collected on membrane filters (Millipore GS with pore size $0.22 \mathrm{~mm}$ ), and the specific activity of ${ }^{33} \mathrm{P}$ was used in all quantifications. Metabolites were extracted with 5\% ice-cold TCA (trichloroacetic acid) for $5 \mathrm{~min}$, and extracted inorganic and organic $\mathrm{P}$ were used as measures of inorganic and organic cytoplasmic $\mathrm{P}$, respectively. TCA-insoluble polyphosphates were determined by hot water extraction according to the method of Fitzgerald \& Nelson (1966). TCA and hot water insoluble material was considered to be DNA+RNA+phospholipid P. All determinations were done in triplicate, and the coefficient of variation in the determinations was $<12 \%$.

Concentration of $\mathrm{P}$ was calculated from ${ }^{33} \mathrm{P}$ counts by assuming the same specific activity in all pools. Spcctrophotometrical measurement of total P (cf, below) and total ${ }^{33} \mathrm{P}$ was used in the calculations.

Measurement of uptake and uptake kinetics of phosphate. At early stationary phase, the initial uptake rate of dissolved inorganic phosphate $\left(P_{\mathrm{i}}\right)$ of the bacteria was measured at 8 or 9 different $P_{1}$ concentrations

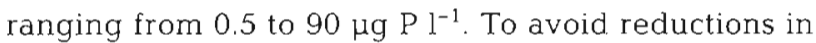
the $P_{\mathrm{i}}$ concentration and thus concentration-dependent non-linearity in the uptake rate during the incubations, the cultures were diluted 100 to $200 \times$ with P-free medium and allowed to equilibrate for $30 \mathrm{~min}$ to reestablish the external equilibrium concentration. Turnover experiments of $P_{\mathrm{i}}$ (cf. below) demonstrated that such dilutions did not affect the $P$ status of the cells or their uptake characteristics. Sub-samples of $50 \mathrm{ml}$ were transferred to acid-washed glass bottles. An appropriate amount of $P_{\text {s }}$ supplemented with ${ }^{33} \mathrm{P}_{-} \mathrm{PO}_{4}$ was added, after which the culture was strongly shaken for $10 \mathrm{~s}$. Six $1 \mathrm{ml}$ samples were removed during the first $6 \mathrm{~min}$ of incubation, collected on membrane filters (Millipore GS, pore size $0.22 \mathrm{~mm}$ ) applying weak suction, and repeatedly washed with the mineral medium of Guillard \& Lorenzen (1972) to remove dissolved ${ }^{33} \mathrm{P}$. For the highest concentration the uptake was followed for approximately $2 \mathrm{~h}$.

At each concentration the uptake rate of $P_{\mathrm{i}}$ was calculated as the slope of the uptake curve by linear regression of uptake versus time. In all incubations the uptake was linear for the first $6 \mathrm{~min}$. Conversion to $P_{\mathrm{i}}$ uptake rates were made on the basis of the specific activity of the $P_{\mathrm{i}}$ mixture. The initial uptake rates $(u)$ were related to ambient concentrations $\left(P_{\mathrm{i}}\right)$ using the Michaelis-Menten type hyperbola (Eq. 1). The parameters of the equation $\left(U_{\mathrm{m}}\right.$ and $\left.k_{\mathrm{m}}\right)$ were estimated by non-linear regression using the Simplex algorithm (SYSTAT, Inc.).

The uptake rate of ambient $P_{\mathrm{i}}$ (turnover experiments) was measured as for $P_{i}$ uptake rates, after the addition of tracer only. In these experiments an exponential decrease in uptake of tracer with time was obtained. The initial uptake rate constant was estimated by linear regression of $\ln$ (dissolved ${ }^{33} \mathrm{P}$ ) versus time for the linear part of the curve. The absolute value of the slope of the line was used as an estimate of the uptake rate constant

Analytical methods. Samples for recording optical density and fractionation of ${ }^{33} \mathrm{P}$ were collected aseptically through a sample port. Samples for analysis of particulate carbon and nitrogen were collected on acid-washed and ignited glass fibre filters (Whatman $\mathrm{GF} / \mathrm{F}$ ) and washed with carbon-free medium to reduce problems with background due to dissolved carbon. Different culture volumes were filtered, and retention efficiency of cells for comparable volumes was determined by comparing particulate ${ }^{33} \mathrm{p}$ retained on $\mathrm{GF} / \mathrm{F}$ versus membrane filters. Carbon and nitrogen on GF/F filters were measured with a Carlo Erba elemental analyser (model 1104), after removal of inorganic carbon by $\mathrm{HCl}$ fume. Bacterial carbon and nitrogen were determined as the slope of the retention corrected values versus filtered volume by linear regression. This procedure allowed correction for residual dissolved organic carbon on the filters. Total phosphorus was determined as dissolved inorganic phosphorus after persulphate oxidation according to Koroleff (1976). 
The radioactivity in water samples and on the filters was assayed in a Packard model 3375 scintillation counter using Optifluor (Packard) as the scintillation cocktail. Counting efficiency was found to be equal for water and filter samples.

Calculations. The realized maximum growth rate $\left(\mu_{m}, c f\right.$. Table 1$)$ of the strains was estimated both on a $\mathrm{C}$ and a $\mathrm{P}$ basis during exponential growth by linear regression of $\ln C$ or $\ln \mathrm{P}$ versus time. The release rates of $\mathrm{P}$ were calculated as the difference between gross uptake of $P_{1}$ and $P$ utilized for growth, using Eq. (2). In the calculations, negligible death rates of the bacteria were assumed.

\section{RESULTS AND DISCUSSION}

\section{Growth kinetics of cultures}

Strain 3h grew exponentially from the beginning, in terms of both cellular $C$ and $P$ (Fig. $1 A, B$ ), and the 2 parallel cultures exhibited fairly identical growth patterns (Fig. 1A). Maximum growth rates were 0.132 and $0.130 \mathrm{~h}^{-1}$ on a $\mathrm{C}$ and a $\mathrm{P}$ basis, respectively. Whereas the increase in cellular $P$ levelled off due to

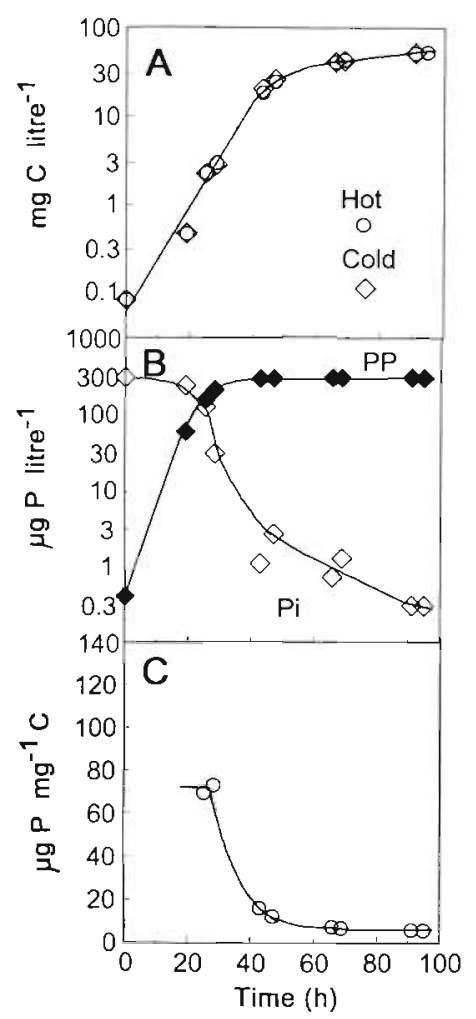

Fig. 1. Time course of bacterial biomass as (A) carbon, (B) cellular $\mathrm{P}(\mathrm{PP})$ and dissolved inorganic phosphate $\left(P_{\mathrm{j}}\right)$, and $(\mathrm{C})$ cellular P quota of strain $3 \mathrm{~h}$. Curves drawn by eye depletion of $P_{\mathrm{i}} 40 \mathrm{~h}$ after inoculation (Fig. 1B), the increase in biomass continued for an extra $40 \mathrm{~h}$ (Fig 1A). This continued increase in biomass must have been based on cellular $\mathrm{P}$, as reflected in the continued decrease in the P:C ratio $\left(Q_{\mathrm{P}}\right)$ of the cells after depletion of $P_{\mathrm{i}}$ (Fig. 1C). $Q_{\mathrm{P}}$ was not calculated in cases where optical density readings used to determine biomass were close to the detection limit. Averaging the values for the exponential phase, the total range in $Q_{\mathrm{P}}$ was 5.7 to $72 \mu \mathrm{g} \mathrm{P}(\mathrm{mg} \mathrm{C})^{-1}$. The average concentration of $P_{\mathrm{i}}$ during early stationary phase was $0.32 \mu \mathrm{g} \mathrm{P} \mathrm{^{-1 }}$, whereas dissolved organic $\mathrm{P}$ averaged $0.6 \mu \mathrm{g} \mathrm{P}^{-1}$ (not shown). The cellular nitrogen quota of strain $3 \mathrm{~h}$ was $130 \mu \mathrm{g} \mathrm{N}(\mathrm{mg} \mathrm{C})^{-1}$ at early stationary phase (not shown).

The growth of strain $2 \mathrm{~g}$ progressed in a similar manner (Fig. 2). The maximum growth rate was 0.174 and $0.162 \mathrm{~h}^{-1}$ on a $\mathrm{C}$ and a $\mathrm{P}$ basis, respectively. Biomass for this strain also continued to increase after depletion of $P_{\mathrm{i}}$, which again was reflected in the total variation in $Q_{\mathrm{P}}\left[2.6\right.$ to $46 \mu \mathrm{g} \mathrm{P}\left(\mathrm{mg} \mathrm{C}^{-1}\right.$; Fig. 2C]. The average value during exponential growth was $34 \mu \mathrm{g} \mathrm{P}\left(\mathrm{mg} \mathrm{C}^{-1}\right.$. During early stationary phase the average concentration of dissolved inorganic and organic $P$ averaged 0.15 and $0.4 \mathrm{ug} \mathrm{P} \mathrm{l}^{-1}$, respectively. The cellular nitrogen quota of

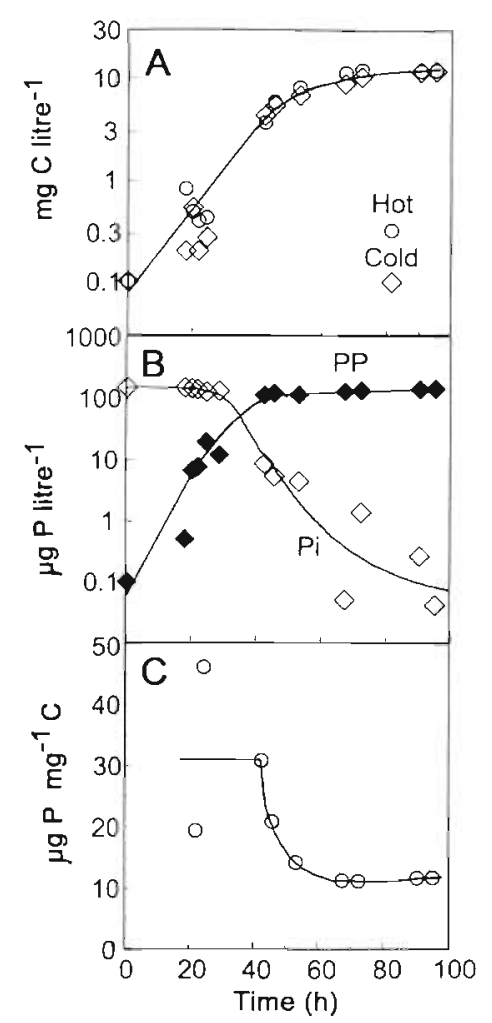

Fig. 2. Time course of bacterial biomass as (A) carbon, (B) cellular P (PP) and dissolved inorganic phosphate $\left(P_{1}\right)$, and $(\mathrm{C})$ cellular $P$ quota of strain $2 \mathrm{~g}$. Curves drawn by eye 
Table 2. Kinetic parameters estimated by fitting the Michaelis-Menten model to the uptake data of strains $3 \mathrm{~h}$ and $2 \mathrm{~g}$ (Fig. 3 ). Results are given for normalization to both cellular $\mathrm{P}\left(A_{\mathrm{P}}\right)$ and cellular $\mathrm{C}\left(A_{C}\right)$. For dimensions see Table 1

\begin{tabular}{|c|c|c|c|c|c|c|c|}
\hline & $k_{\mathrm{m}}$ & $U_{\mathrm{m}}$ & $V_{\mathrm{m}}$ & $A_{P}$ & $A_{C}$ & $r^{2}$ & $N$ \\
\hline Strain 3h & $3.0 \pm 0.6$ & $9.4 \pm 0.5$ & $54 \pm 3$ & $3.2 \pm 0.6$ & $18.0 \pm 3$ & 0.974 & 8 \\
\hline Strain $2 \mathrm{~g}$ & $3.3 \pm 0.8$ & $2.4 \pm 0.2$ & $30 \pm 3$ & $0.74 \pm 0.20$ & $9.3 \pm 2.5$ & 0.933 & 8 \\
\hline
\end{tabular}

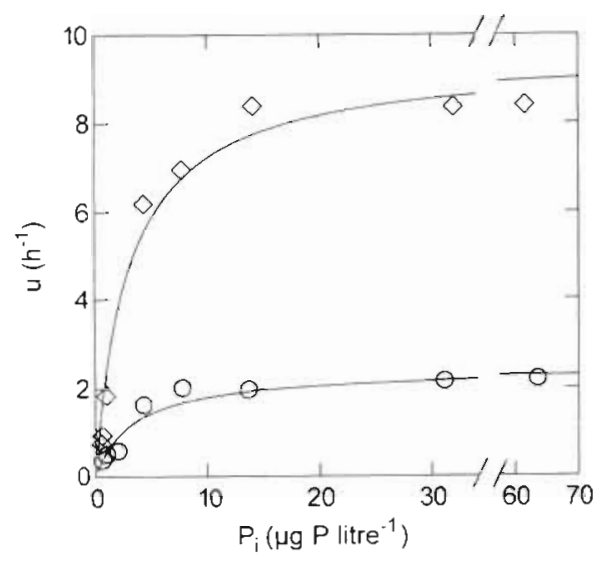

Fig. 3. Phosphate uptake kinetics of strain $3 \mathrm{~h}(\diamond)$ and $2 \mathrm{~g}(0)$ at early stationary phase. Lines represents model curves (cf. Table 2)

strain $2 \mathrm{~g}$ was $208 \mu \mathrm{g} N(\mathrm{mg} \mathrm{C})^{-1}$ at early stationary phase (not shown).

\section{Uptake kinetics of dissolved inorganic phosphate and phosphorus storage capacity}

Typical saturation kinetics was observed for the initial $P_{1}$ uptake rate of both strains (Fig. 3). For both strains, saturation of the uptake occurred at $P_{\mathrm{j}}$ concentrations $>10 \mu \mathrm{g} \mathrm{P} l^{-1}$. The MichaelisMenten model described the data in a good manner (Table 2). The 2 strains exhibited comparable half-saturation constants, but differed by a factor of nearly 4 in P-based maximum uptake rate $\left(U_{m}\right)$. This entails a comparable difference in P-normalizcd affinity. When the kinetic parameters are normalized to carbon, the differences in maximum uptake rate and affinity are so evident due to the higher $Q_{\mathrm{p}}$ of strain $2 \mathrm{~g}$ compared to strain $3 \mathrm{~h}$ during the early stationary phase.

An evaluation of the ability of the 2 strains to maintain a high uptake rate for prolonged periods demonstrated clear differences (Fig. 4). Whereas

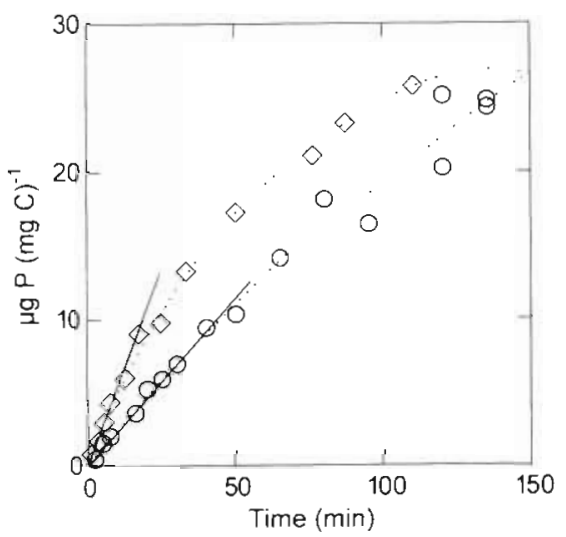

Fig. 4. Time course in $P$ uptake of strain $3 \mathrm{~h}(\diamond)$ and $2 \mathrm{~g}(0)$ at saturating concentrations of $P_{1}$. Cells from early stationary phase. Solid lines indicate initial uptake rate

strain 3 h maintained the maximum uptake rate only for 10 min, strain $2 \mathrm{~g}$ maintained its maximum rate for approximately $50 \mathrm{~min}$ after phosphate was added. Although strain $3 \mathrm{~h}$ demonstrated an initial uptake rate 4 times higher than that of strain $2 \mathrm{~g}$, the total uptake on a $\mathrm{C}$ basis was similar after approximately $2 \mathrm{~h}$.

The change in cellular $P$ quota $\left(Q_{p}\right)$ after a pulse of $P_{\text {i }}$ high enough to saturate the uptake rate revealed the same differences between strains as suggested by the uptake kinetics (Fig. 5). A more rapid initial in-
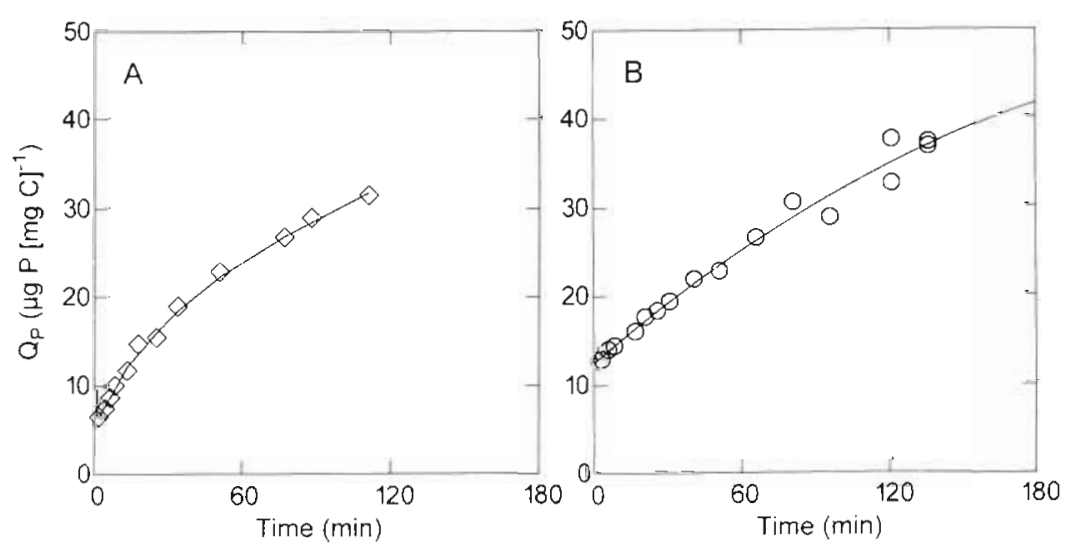

Fig. 5. Increase in cellular $P: C$ ratio $\left(Q_{p}\right)$ of $(A)$ strain $3 h(\diamond)$ and $(B)$ strain $2 g(O)$ after addition of surplus of $P_{1}$. Cells from early stationary phase. Lines are model. curves (cf. text) 
Table 3. Measured specific uptake rate of ambient $P_{1}(u)$ and estımated specific release rates of $\mathrm{P}\left(S R_{\mathrm{p}}\right)$ during different growth phases of the cultures

\begin{tabular}{|llccc|}
\hline & Growth conditions & $u$ (h ') & $S R_{\mathrm{p}}(\mathrm{h}$ ', & $S R_{\mathrm{p}}: u$ \\
\hline \multirow{2}{*}{ Strain 3h } & Exponential, surplus $P_{1}\left(\mu=\mu_{\mathrm{m}}\right)$ & 1.19 & 1.1 & 0.92 \\
& Exponential, $P_{1}$ depleted $\left(\mu=\mu_{\mathrm{m}}\right)$ & 0.43 & 0.42 & 0.98 \\
& Early stationary $\left(\mu<0.05 \mu_{\mathrm{m}}\right)$ & 0.91 & 0.91 & 1.00 \\
& & & & \\
Strain 29 & Exponential, surplus $P_{1}\left(\mu=\mu_{\mathrm{m}}\right)$ & 2.6 & 2.4 & 0.93 \\
& Late exponential $\left(\mu=0.66 \mu_{\mathrm{m}}\right)$ & 2.0 & 2.0 & 1.00 \\
& Early stationary $\left(\mu<0.05 \mu_{\mathrm{m}}\right)$ & 0.10 & 0.10 & 1.00 \\
\hline
\end{tabular}

Table 4. Absolute and percent distribution of phosphorus in biochemical pools of the 2 strains in early stationary phase.

\begin{tabular}{|lrrrr|} 
& \multicolumn{2}{c}{ Strain $2 \mathrm{~g}$} & \multicolumn{2}{c|}{ Strain $3 \mathrm{~h}$} \\
& $\mu \mathrm{g} \mathrm{P}\left(\mathrm{mg} \mathrm{C}^{-1}\right.$ & $\%$ & $\mu \mathrm{g} \mathrm{P}\left(\mathrm{mg} \mathrm{C}^{-1}\right.$ & $\%$ \\
\hline Cytoplasmic $P_{\mathrm{I}}$ & 1.3 & 10.3 & 0.3 & 5.9 \\
Cytoplasmic organic P & 0.2 & 1.9 & 1.0 & 17.6 \\
TCA-jnsoluble polyphosphate & 3.2 & 25.3 & 1.0 & 16.8 \\
DNA+RNA+lipid & 7.9 & 62.4 & 3.5 & 59.7 \\
Sum & 12.6 & 100 & 5.9 & 100 \\
\hline
\end{tabular}

No detectable release of ${ }^{33} \mathrm{P}$ from the cells was found in strain $3 \mathrm{~h}$ during early stationary phase after pulsing with $2 \mu$ M non-radioactive phosphate. suggesting this method to be inadequate for measurements of $\mathrm{P}$ release under these experimental conditions.

\section{Fractionation of cellular phosphorus}

Fractionation of cellular $\mathrm{P}$ revealed that for both strains approximately $60 \%$ of the $\mathrm{P}$ was bound in structural compounds at early stationary phase (Table 4). For other cellular pools some variation was observed between the 2 strains. TCA-insoluble polyphosphates made up a sixth of total $P$ in strain $3 \mathrm{~h}$, whereas they constituted a fourth of cellular $P$ in strain $2 \mathrm{~g}$ Total cytoplasmic $P$ of the 2 species differed by a factor of approximately 2 , with the highest content recorded in strain 3h. For cytoplasmic $P$, a corresponding difference was observed between the crease was observed for strain $3 \mathrm{~h}$, with clear indications of saturation in $Q_{p}$ after $2 \mathrm{~h}$. For strain $2 \mathrm{~g}$ only a moderate tendency toward saturation in $\mathrm{P}$ content was observed during the incubation $(2.3 \mathrm{~h})$. Fitting the data to an exponential model indicated a difference of a factor of 3 in the rate constant for the increase in $Q_{p}$. Saturation levels in $Q_{\mathrm{p}}$ (i.e. $Q_{\mathrm{S}}$ ) were 36 and $65 \mu \mathrm{g}$ P $(\mathrm{mg} \mathrm{C})^{-1}$ for strains $3 \mathrm{~h}$ and $2 \mathrm{~g}$, respectively. The more rapid feed-back on maximum uptake rate for strain $3 \mathrm{~h}$ (Fig. 4) may have resulted from a more rapid saturation of cellular P pools for this strain. Results for both strains suggest that in the early stationary phase a negative feed-back on $P_{\text {, }}$ uptake rate is manifested when $Q_{p}$ approximately doubles compared to the initial value

\section{Release rates of phosphorus from cells}

Using Eq. (2), uptake rate and the data given in Figs. 1 \& 2, release rates of $P$ have been calculated (Table 3). For both strains a clear effect of phosphorus status on $\mathrm{P}$ release rates was observed, with higher rates under P-sufficient conditions. Under P-sufficient conditions, the release rates are more comparable for the 2 strains than under strong P limitation. In the latter case, release rates of $P$ were considerably higher for strain $3 \mathrm{~h}$. Under all conditions, more than $90 \%$ of the $P$ taken up was released.
2 strains, but the highest content was observed in strain $2 g$ (Table 5).

\section{Summary of properties relevant for evaluation of competitive ability}

A summary of kinetic parameters relevant for evaluation of competitive ability under $\mathrm{P}$ limitation is pre-

Table 5. Summary of 1 mportant kinetic properties which determine the competıtuve ability for phosphorus of the 2 strains under $\mathrm{P}$ limitation. Standard error of the mean included for measured parameters when available

\begin{tabular}{|c|c|c|c|}
\hline Variable & Strain 3h & Strain $2 g$ & Dimension \\
\hline$\mu_{m}$ & $0.13 \pm 0.01$ & $0.17 \pm 0.02$ & $h^{-1}$ \\
\hline$Q_{11}$ & $5.7 \pm 0.5$ & $13 \pm 1$ & $\mu g P(m g C)^{-1}$ \\
\hline$Q_{\mathrm{m}}$ & $72 \pm 2$ & $34 \pm 7$ & $\mu \mathrm{g} P(\mathrm{mg} \mathrm{C})^{-1}$ \\
\hline$Q_{\mathrm{m}}: Q_{0}$ & 13 & 2.7 & Dimensionless \\
\hline$Q_{3}$ & 36 & 65 & $\mu g P(m g C)^{-1}$ \\
\hline$Q_{\mathrm{s}}: Q_{0}$ & 6.3 & 5.2 & Dimensionless \\
\hline$U_{\mathrm{m}}$ & $9.4 \pm 0.5$ & $2.4 \pm 0.2$ & $\mathrm{~h}^{-1}$ \\
\hline$A_{p}$ & $3.2 \pm 0.6$ & $0.74 \pm 0.20$ & $1(\mu g P h)^{-1}$ \\
\hline$S R_{p}$ & 0.91 & 0.10 & $\mathrm{~h}^{-1}$ \\
\hline$P^{\cdot n}$ & 0.33 & 0.20 & $\mu g P^{-1}$ \\
\hline$P_{C}$ & $0.32 \pm 0.02$ & $0.15 \pm 0.07$ & $\mu \mathrm{gPl} \mathrm{P}^{-1}$ \\
\hline \multicolumn{4}{|c|}{ "Calculated assuming $\mu=0.25 \mu_{m}$} \\
\hline
\end{tabular}


sented in Table 5. $Q_{0}$ and $Q_{\mathrm{m}}$ are given averages of measured values of $Q_{p}$ during early stationary phase and exponential phase, respectively. The maximum storage capacity $\left(Q_{\mathrm{S}}\right)$ is estimated from extrapolation of the long term increase in $Q_{p}$ under saturating conditions of $P_{\mathrm{i}}$ uptake (Fig. 5), $P_{\mathrm{C}}$ is given a parameter value equal to measured concentration during early stationary phase, whereas $P^{*}$ is estimated from Eq. (6). Other values are taken from Tables $2 \& 3$.

One inconsistency is observed for strain $3 \mathrm{~h}$, because the value of $Q_{\mathrm{m}}$ is larger than the value of $Q_{\mathrm{S}}$. There is no evident explanation for this discrepancy. It should be noted, however, that $Q_{\mathrm{S}}$ of strain $2 \mathrm{~g}$ is based on extrapolation far beyond the observed values. Both $Q_{\mathrm{S}}$ values should therefore be used with caution. However, except for extremely pulsed or transient $P_{\mathrm{i}}$ supply modes, this parameter is not critical.

The summary in Table 5 suggests that the 2 species have different competitive strategies. Strain $3 \mathrm{~h}$ seems to have a better competitive ability for $\mathrm{P}$ than strain $2 \mathrm{~g}$ at transient or pulsed supply modes of $P_{\mathrm{j}}$. This is reflected in $U_{\mathrm{m}}$ which is a factor of 4 higher. Strain $2 \mathrm{~g}$, on the other hand, is a better competitor at uniform or moderately pulsed $P_{1}$ supply modes. This is based on $P_{\mathrm{C}}$, which is a factor of 2 lower for strain $2 \mathrm{~g}$ than for strain $3 \mathrm{~h}$. It should be noted that the difference in $P_{\mathrm{C}}$ results from the superior ability of strain $2 \mathrm{~g}$ to retain acquired $P$ (cf. Eqs. 8 \& 9), i.e. its low release rate of $P$ ( $S R_{\mathrm{p}}$, cf. Eq. 8). If an evaluation of competitive ability was based on uptake kinetics, using solely $U_{\mathrm{m}}$ and $A_{\mathrm{p}}$, one would have concluded that compared to strain $2 g$. strain $2 \mathrm{~h}$ is the superior competitor for $\mathrm{P}$ whether the supply mode of $P_{\mathrm{i}}$ is pulsed or uniform.

\section{Comparison of kinetic parameters and competitive ability with other planktonic bacteria and algae}

The minimum cell quota $\left(Q_{0}\right)$ of the 2 strains $3 \mathrm{~h}$ and $2 \mathrm{~g}$ are in the lower end of what is reported for heterotrophic bacteria (cf. Vadstein 1998). Yet $Q_{0}$ estimated in the present study is considerably higher than $Q_{0}$ recorded for eucaryotic algae, and for one strain even higher than $Q_{0}$ for cyanobacteria (Table 6, and see Vadstein \& Olsen 1989, Andersen 1997). Whereas the $Q_{\mathrm{m}}: Q_{0}$ ratio is comparable to the typical ratio in cyanobacteria and algae, it seems that green algae in particular have a considerably higher ability than bac-

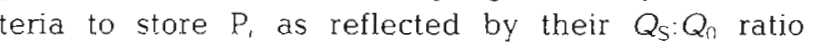
(Table 6, and Andersen 1997). Measured N:C ratios of the investigated bacterial strains are 130 and 208 (g N $(\mathrm{mg} \mathrm{C})^{-1}$, and somewhat higher than normally found in N-saturated eucaryotic algae (Gismervik et al. 1996).

There is a limited number of heterotrophic bacteria for which uptake and release of phosphorus have been determined. The rates for maximum uptake $\left(U_{\mathrm{m}}\right)$ and affinity $\left(A_{\mathrm{p}}\right)$ determined in the present study fall within the range reported previously (cf. Vadstein \& Olsen 1989). Compared to eucaryotic algae $U_{\mathrm{m}}$ and particularly $A_{p}$ are considerably higher for the 2 strains investigated here (Table 6, and Andersen 1997). When compared with cyanobacteria the 2 strains have considerably higher $A_{p}$ and considerably lower $U_{m}$ (Table 6). Although release of $P$ is well documented for heterotrophic bacteria (see above), release rates appropriate for comparison to those presented here are not available. Release rates may, however, be calculated from the data reported by Vadstein \& Olsen (1989) using Eq. (3). Such calculations give $S R_{p}$ values of 0.02 to $0.09 \mathrm{~h}^{-1}$ for P-limited bacteria, which are certainly considerably lower than those recorded for strain $3 \mathrm{~h}$, which attained the highest rates in this investigation. Also, few data on release rates for cyanobacteria and algae are available in the literature. Whereas typical release rates of green algae seem to be considerably lower than those recorded for heterotrophic bacteria, release rates of cyanobacteria are more comparable (Table 6).

It has been claimed that heterotrophic bacteria are superior competitors compared to algae, both at high and low concentrations of $P_{\mathrm{i}}$ (e.g. Currie \& Kalff 1984a, b), i.e. at both pulsed and uniform supply modes. If based on uptake kinetics only, similar conclusions may be reached from the data for the 2 bacterial strains used in the present study (cf. Table 6). If the release rate of $\mathrm{P}$ is considered, a rate that has been shown to have a dramatic effect on the outcome of a competition situation (Olsen et al. 1989), the conclusion from the comparisons is somewhat different. Typical values of kinetic parameters for cyanobacteria and green algae

Table 6. Typical kinetic properties predicting competitive ability for phosphorus of cyanobacteria and green algae from Olsen 1988). The background data and references are available on request from the author of this paper

\begin{tabular}{|c|c|c|c|}
\hline Variable & Cyanobacteria & Green algae & Dimension \\
\hline$\mu_{m}$ & 0.034 & 0.075 & $h^{-1}$ \\
\hline$Q_{0}$ & 4.6 & 2.1 & $\mu \mathrm{g} P(\mathrm{mg} \mathrm{C})^{-1}$ \\
\hline$Q_{\mathrm{m}}: Q_{0}$ & 5.7 & 7.4 & Dimensionless \\
\hline$Q_{5}: Q_{0}$ & 12 & 23 & Dimensionless \\
\hline$U_{\mathrm{m}}$ & 14 & 1.8 & $h^{-1}$ \\
\hline$A_{P}$ & 0.39 & 0.15 & $1(\mu g P h)^{-1}$ \\
\hline$k_{\mathrm{m}}$ & 36 & 12 & $\mu g \mathrm{Pl}^{-1}$ \\
\hline$S R_{\mathrm{p}}$ & $0.11^{\mathrm{d}}$ & 0.01 .5 & $h^{-1}$ \\
\hline$P^{\cdot}$ & 0.30 & 0.21 & $\mu g \mathrm{Pl}^{-1}$ \\
\hline$P_{C}$ & 0.28 & 0.10 & $\mu g P l^{-1}$ \\
\hline \multicolumn{4}{|c|}{$\begin{array}{l}\text { "Value for severely starved Microcystis aeruginosa }(\mu= \\
\left.0.25 \mu_{\mathrm{n}}\right)\end{array}$} \\
\hline
\end{tabular}


(Table 6) emerging from a review made by Olsen (1988) suggest that cyanobacteria may be better competitors than heterotrophic bacteria at transient supply modes of $P_{\mathrm{i}}$ (typical $U_{\mathrm{m}}$ of $14 \mathrm{~h}^{-1}$ ), whereas green algae have a comparable or better ability than heterotrophic bacteria to compete for $\mathrm{P}$ at uniform supply modes of $P_{\mathrm{i}}$

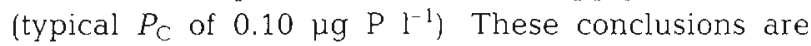
based on relatively few data and should therefore be considered with caution. They do, however, exemplify that conclusions regarding competitive ability based on uptake kinetics are not straightforward. Extrapolation to natural ecosystems may be even more problematic as selective loss rates of a superior competitor for a limiting nutrient may facilitate coexistence (Pengerud et al. 1987, Thingstad et al. 1997). The high release rates of $\mathrm{P}$ from heterotrophic bacteria may, however, explain why bacteria often appear to be sub-saturated or limited by phosphorus in natural ecosystems (Vadstein et al. 1988, Morris \& Lewis 1992, Thingstad et al. 1997, Vadstein 1998).

Acknowledgements. This study was financed by the Research Council of Norway. Egil Sakshaug and Yngvar Olsen provided helpful comments on earlier versions of the manuscript.

\section{LITERATURE CITED}

Andersen T (1997) Pelagic nutrient cycles. Herbivores as sources and sinks. Ecological Studies 129. Springer, Berlin

Bieleski RL, Ferguson IB (1983) Physiology and metabolism of phosphate and its compounds. In: Läuchli A, Bieleski RL (eds) Inorganic plant nutrition, Encyclopedia of plant physiology, New series, Vol 15A. Springer, Berlin, p $422-449$

Cembella AD, Antia NJ, Harrison PJ (1984) The utilization of inorganic and organic phosphorus compounds as nutrients by eukaryotic microalgae: a multidisciplinary perspective: Part 1. CRC Crit Rev Microbiol 10:317-391

Currie DJ, Kalff J (1.984a) A comparison of the abilities of freshwater algae and bacteria to acquire and retain phosphorus. Limnol Oceanogr 29:298-310

Currie DJ, Kalff J (1984b) Can bacteria outcompete phytoplankton for phosphorus? A chemostat test. Microb Ecol 10:205-216

Droop MR (1968) Vitamin $B_{12}$ and marine ecology IV. The kinetics of uptake, growth and inhibition in Monochrysis lutheri. J Mar Biol Assoc UK 48:689-733

Droop MR (1983) 25 years of algal growth kinetics. A personal view. Bot Mar 26:99-112

Fitzgerald GP, Nelson TC (1966) Extractive and enzymatic analysis for limiting or surplus phosphorus in algae. J Phycol 2:141-144

Gismervik I, Andersen T, Vadstein O (1996) Pelagic food webs and eutrophication of coastal waters: impact of graz-

Editorial responsibility: Frede Thingstad,

Bergen, Norway ers on algal development. Mar Pollut Bull 33:22-35

Guillard RRL, Lorenzen CJ (1972) Yellow-green algae with chlorophyllide c. J Phycol 8:10-14

Healey FP (1980) Slope of the Monod equation as an indicator of advantage in nutrient competition. Microb Ecol 5 . $281-286$

Jansson M (1988) Phosphate uptake and utilization by bacteria and algae. Hydrobiologia 170:177-189

Koroleff F (1976) Determination of phosphorus. In: Girasshoff $\mathrm{K}$ (ed) Methods of seawater analysis. Verlag Chemie, Weinheim, p 117-125

Lean DRS, Nalewajko C (1976) Phosphate exchange and organic phosphorus excretion by freshwater algae. J Fish Res Board Can 33:1312-1323

Morris DP, Lewis Jr WM (1992) Nutrient limitation of bacterioplankton growth in Lake Dillon, Colorado. Limnol Oceanogr 37:1179-1192

Olsen Y (1988) Phosphate kinetics and competitive ability of planktonic blooming cyanobacteria under variable phosphate supply. Dr Techn thesis, University of Trondheim

Olsen Y (1989) Evaluation of competitive ability of Staurastrum luetkemuellerii (Chlorophyceae) and Microcystis aeruginosa (Cyanophyceae) under P limitation. J Phycol 25:486-499

Olsen Y, Vadstein O, Jensen A, Andersen T (1989) Competition between Staurastrum luetkemullerii (chlorophycae) and Microcystis aeruginosa (cyanophycae) under varying modes of phosphate supply. J Phycol 25:499-508

Pengerud B, Skjoldal EF, Thingstad TF (1987) The reciprocal interaction between degradation of glucose and ecosystem structure. Studies in mixed chemostat cultures of marine bacteria, algae and bacterivorous nanoflagellates. Mar Ecol Prog Ser 35:111-117

Robertson BR, Button DK (1979) Phosphate-limited culture of Rhodotorula rubra: kinetics of transport, leakage, and growth. J Bacteriol 138:884-895

Rosenberg H, Russel LM, Jacomb PA, Chegwidden K (1982) Phosphate exchange in the Pit transport system in Escherichia coli. J Bacteriol 149:123-130

Thingstad TF, Hagström $\AA$, Rassoulzadegan F (1997) Accumulation of degradable DOC in surface waters: is it caused by a malfunctioning microbial loop? Limnol Oceanogr 42:398-404

Tilman D (1977) Resource competition between planktonic algae: an experimental and theoretical approach. Ecology $58: 338-348$

Tilman D, Kilham SS, Kilham P (1982) Phytoplankton community ecology: the role of limiting nutrients. Annu Rev Ecol Syst $13: 348-372$

Vadstein $O$ (1998) Heterotrophic, planktonic bacteria and cycling of phosphorus: phosphorus requirements, competitive ability and food web interactions. Adv Microb Ecol 16 (in press)

Vadstein O, Jensen A, Olsen Y, Reinertsen H (1988) Growth and phosphorus status of limnetic phytoplankton and bacteria. Limnol Oceanogr 33:489-503

Vadstein $O$. Olsen $\mathrm{Y}(1989)$ Chemical composition and $\mathrm{PO}_{4}$ uptake kinetics of limnetic bacterial communities cultured in chemostat under $\mathrm{P}$ limitation. Limnol Oceanogr 34: $939-946$

Submitted: February 20, 1997, Accepted: September 12, 1997 Proofs received from author(s): January 29, 1998 